$\begin{array}{ll}\text { Research Square } & \begin{array}{l}\text { Preprints are preliminary reports that have not undergone peer review. } \\ \text { They should not be considered conclusive, used to inform clinical practice, } \\ \text { or referenced by the media as validated information. }\end{array}\end{array}$

\title{
Principal component regression of carcass traits in meat line funaab alpha chicken genotype
}

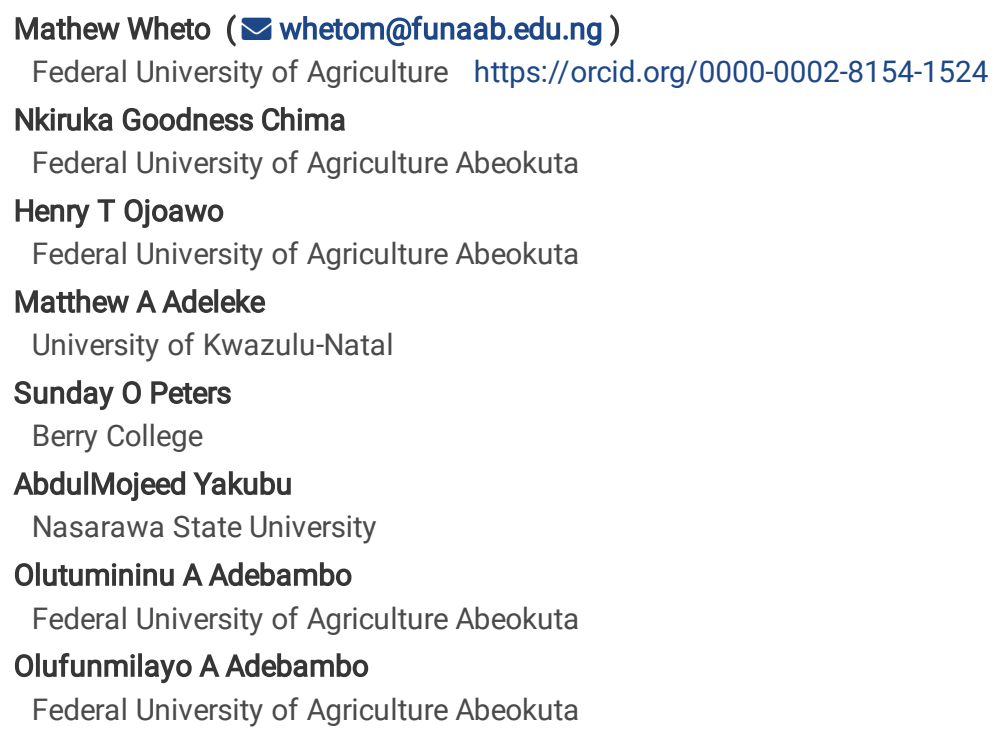

\section{Research Article}

Keywords: FUNAAB Alpha, Principal Component Regression, Carcass, Correlation

Posted Date: November 9th, 2021

DOI: https://doi.org/10.21203/rs.3.rs-985513/v1

License: (c) (i) This work is licensed under a Creative Commons Attribution 4.0 International License. Read Full License 


\section{Abstract}

This study aimed to assess the relationship among carcass traits of meat line FUNAAB Alpha chicken genotype, to identify the components that defined bled weight in them using multivariate principal component regression. A total of 14 different carcass traits from sixty-eight birds were recorded and subjected to one-way analysis of variance to vet for sex effect. Phenotypic relationships among the carcass traits were also established to pave way for the principal component analysis. The results reveal significant effects between the traits measured. The male significantly $(P<0.05)$ had greater mean values for the traits measured. Correlations among the considered carcass traits were found to be positive and significant ranging from $r=0.406(\mathrm{LrWt})$ - 0.981 (EdWt) for the female chicken; $r=0.330$ (Head Wt) - 0.978 (BdWt) for the male chicken. The extracted components PC1 to PC7 contributed $95.66 \%$ with PC1 accounting for $68.68 \%$ of the variability in the original parameters. Communality estimates varied from 0.466 (thigh weight) to 0.983 (liver weight). In the principal component regression models, Eviscerated weight accounted for $95 \%$ of the variation observed in bled weight. The use of PC1 as a single predictor, explained $96.4 \%$ of the variability, whilst combining PC1 and PC4 showed improvements in the variance explained $\left(R^{2}=96.7 \%\right)$ with a lower Mallow's cp (5.31). Using the principal components scores from the chicken morphometric traits was more appropriate than using the original traits in bled weight prediction.

\section{Introduction}

Poultry production in developing countries is a fast growing sub-sector of agriculture that is quick in terms of shorter production cycles (Magothe et al., 2012; Mottet and Tempio, 2017; Alabi et al., 2019; Alabi et al., 2020). Products from poultry are one of the most popular options available in Nigeria in reducing protein deficiency and malnutrition in the populace diet (Obasoyo et al., 2005; Anyawu and Okoro, 2006; Ojedapo et al., 2015). The call for the improvement and development of chicken breeds that are indigenous to Nigeria led to the development of the FUNAAB Alpha chicken breed (Broiler and dual purpose). The breed was developed at the Federal University of Agriculture, Abeokuta, Nigeria, using the Naked and Frizzled feather chicken genotype (Broiler type) having over six generations through cross breeding with some exotic lines to maximise growth and their productive performance (Adebambo et al., 2018). This development has been effected for improved production without compromise to its climatic adaptation and diseases susceptibility (Saleh et al., 2017).

The growth process within the indigenous chicken is a complex one that relates to increasing body cells and volume. Growth mechanisms and processes are mostly too multifaceted to be explained with univariate analysis. This can be because of the biological linkage caused by gene loci and pleiotropic effect. The principal component analysis which is a multivariate procedure could better solve the problems associated with the univariate analysis of growth and its observed traits. This is because it reduces related variables into a lesser numbers of uncorrelated variables called principal components (Kor et al., 2006; Rosario et al., 2008; Amao, 2018). The principal component analysis is a tool for exploratory data and is adapted for making predictive models (Acha, 2012). It has been used to describe the inter-relationship between body measurements and size in chickens (Yakubu et al., 2009a; Udeh and Ogbu, 2011; Akporhuarho and Omoikhoje, 2017). In animal genetics and improvement, principal components simultaneously considers certain attributes that may be utilised for selection purposes. An important aspect is that every principal component explains a certain percentage of the total variance with the first principal component explaining the highest percentage of this variance (Pinto et al., 2006). This study was aimed at analyzing the principal component regression of carcass traits of meat line FUNAAB Alpha Chicken Genotype. The outcome could aid the management and subsequent selection towards genetic improvement of the indigenous stock.

\section{Materials And Methods}

\section{Experimental site}

The study was conducted at PEARL (Program for Emerging Agricultural Research Leaders) Poultry Breeding unit of the Directorate, University Farms (DUFARMS), Federal University of Agriculture, Abeokuta (FUNAAB), Ogun State, Nigeria. The area lies in the South-western part of Nigeria, it is located within the Longitude $7^{0} 10^{0} \mathrm{~N}$ and Latitude $3^{0} 2^{0} \mathrm{E}$, with an average temperature of $33.7^{0} \mathrm{C}$ and relative humidity of $80 \%$ with rainfall of about 1037mm (AGROMET, FUNAAB, 2014).

\section{Experimental birds}

68 birds comprising of 44 males and 24 females randomly selected from the meat line of the improved indigenous chicken, FUNAAB Alpha was used in the experiment. They were generated through artificial insemination at PEARL Farm, Federal University of Agriculture, Abeokuta, Ogun State, Nigeria.

\section{Feeds and feeding}

Feeding was ad libitum; the chicks were on a starter diet that supplied $24 \%$ crude protein and $2900 \mathrm{Kcal} / \mathrm{KgME}$ metabolizable energy from 0 - 4 weeks old and a finisher diet that supplied $23 \%$ crude protein and $3000 \mathrm{Kcal} / \mathrm{KgME}$ metabolizable energy from 5 - 8 weeks. Clean water was given ad libitum throughout the experimental period. 
Data collection: The birds were fasted for 12 hours and slaughtered by severance of the carotid arteries and jugular veins, the blood was drained under gravity and scalded to facilitate plucking and evisceration. The carcass were divided into parts as described by Kleczek et al. (2006). Data were collected on the following traits using a $0.1 \mathrm{~g}$ sensitive scale: bled weight, de-feathered weight, eviscerated weight, breast weight, thigh weight, back weight, shank weight, wing weight, neck weight, head weight, drum stick weight, liver weight, whole gizzard weight, empty gizzard weight.

Statistical analysis: Means, standard errors and coefficient of variation of carcass traits of each sex was obtained using the descriptive statistic of S.A.S (Version 9.1). One-way analysis of variance was used to test for sex effect on the carcass parameters. Pearson correlation coefficients amongst the carcass traits was calculated for both sex and the matrix was the major data required to generate the principal components. Principal component analysis is a method that transforms variables in a multivariate data set $x 1, x 2,-, x p$, into new ones, y1, y2,--, yp which are uncorrelated and account for decreasing proportions in the total variance of the original variables defined as:

$\mathrm{y} 1=\mathrm{a} 11 \mathrm{x} 1+\mathrm{a} 12 \times 2+-+-\mathrm{a} 1 \mathrm{pxp}$

$\mathrm{y} 2=\mathrm{a} 2 \times 1+\mathrm{a} 22 \times 2+\cdots+\mathrm{a} 2 \mathrm{pxp}$

yp = ap1 x1 + ap2 x2 + - + appxp (Adenaike et al., 2015).

The varimax rotation maximized the sum of variances of the aij2 quadratic weight, whilst the stepwise multiple regression procedure was used to obtain models for the prediction of bled weight from the carcass traits (i) and from the established principal components (ii).

$B d W t=a+B i x i+-B k x k-(a)$

$\mathrm{BdWt}=\mathrm{a}+\mathrm{BiPCi}+-\mathrm{BkPCk}-(\mathrm{b})$

Where; BdWt is Bled weight,

a is regression intercept,

$\mathrm{Bi}$ is the ith regression coefficient of the ith linear bled weight measurement,

$\mathrm{Xi}$ is the ith principal component.

The components were extracted until certain stopping criteria were encountered or when the p components were formed. The weights used for the formulation of the principal components were the eigenvectors of the characteristic equation:

$(\mathrm{R}-\lambda 1) \mathrm{a}=0$

Where $\mathrm{R}$ is the correlation matrix,

The $\lambda 1$ are the eigenvalues (variances of the components).

Cumulative proportion variance were employed to determine the number of principal components for extraction. The means, correlation and regression procedures of S.A.S 9.1 statistical package was used for the principal component regression (Adenaike et al., 2015). Mallow's Cp was used to select maximal accurate subsets of predictor variables in the stepwise regression (Liberman and Morris, 2008).

\section{Results}

The means, standard error and coefficients of variation for the carcass traits of meat line of FUNAAB Alpha chicken genotype at 8 weeks of age are presented in Table 1. The results reveals significant effects amongst the traits measured. The male significantly $(P<0.05)$ had greater mean values for the traits measured; from bled weight of $1174 \pm 20.49$ compared to the female with $1030 \pm 29.5$ to liver weight $23.69 \pm 0.56$ and female $20.58 \pm$ 0.68 .

Table l: Means, standard errors and coefficients of variation of carcass traits of meat line of FUNAAB Alpha chicken genotype at 8 weeks of age. 


\begin{tabular}{|c|c|c|c|c|c|c|}
\hline \multirow[t]{2}{*}{ Traits } & \multirow[t]{2}{*}{ No } & \multicolumn{2}{|l|}{ Female } & \multirow[t]{2}{*}{ No } & \multicolumn{2}{|l|}{ Male } \\
\hline & & Mean \pm S.E & CV\% & & Mean \pm S.E & CV\% \\
\hline Bdwt & 24 & $1029.79 \pm 29.5^{b}$ & 14.30 & 44 & $1173.60 \pm 20.46^{a}$ & 11.56 \\
\hline DfdWt & 24 & $996.48 \pm 31.79^{b}$ & 15.63 & 44 & $1117.23 \pm 20.58^{a}$ & 12.22 \\
\hline EdWt & 24 & $814.88 \pm 27.34^{b}$ & 16.44 & 44 & $923.35 \pm 18.58^{a}$ & 13.34 \\
\hline BtWt & 24 & $189.73 \pm 9.03^{b}$ & 23.31 & 44 & $211.93 \pm 6.4^{a}$ & 20.04 \\
\hline TWt & 24 & $117.91 \pm 5.89^{b}$ & 24.46 & 44 & $133.88 \pm 2.65^{\mathrm{a}}$ & 13.13 \\
\hline BaWt & 24 & $142.84 \pm 5.35^{b}$ & 18.36 & 44 & $162.26 \pm 3.66^{a}$ & 14.96 \\
\hline ShkWt & 24 & $50.09 \pm 1.78^{b}$ & 17.37 & 44 & $59.48 \pm 1.34^{a}$ & 15 \\
\hline WingWt & 24 & $104.65 \pm 2.6^{b}$ & 12.23 & 44 & $119.03 \pm 2.27^{a}$ & 12.63 \\
\hline NkWt & 24 & $59.14 \pm 2.02^{b}$ & 16.74 & 44 & $64.93 \pm 1.42^{\mathrm{a}}$ & 14.54 \\
\hline HeadWt & 24 & $36.96 \pm 1.02^{b}$ & 13.53 & 44 & $42.28 \pm 0.8^{a}$ & 12.56 \\
\hline DkWt & 24 & $111.83 \pm 3.85^{b}$ & 16.88 & 44 & $130.41 \pm 3.05^{a}$ & 15.5 \\
\hline WGdWt & 24 & $45.36 \pm 1.71^{b}$ & 18.52 & 44 & $52.39 \pm 1.23^{a}$ & 15.59 \\
\hline EGdWt & 24 & $32.31 \pm 0.9^{b}$ & 13.68 & 44 & $35.60 \pm 0.97^{a}$ & 18.15 \\
\hline LrWt & 24 & $20.58 \pm 0.65^{b}$ & 15.45 & 44 & $23.69 \pm 0.56^{\mathrm{a}}$ & 15.28 \\
\hline
\end{tabular}

$B d w t=$ Bled weight, DfdWt $=$ Defeathered weight, EdWt $=$ Eviscerated weight, BtWt $=$ Breast weight, TWt $=$ Thigh weight

BaWt - Back weight, ShkWt= Shank weight, WingWt=Wing weight, NkWt = Neck weight, HeadWt= Head weight, DkWt = Drum stick weight, WGdWt Whole gizzard weight, EGdWt = Empty gizzard weight, LrWt $=$ Liver weight,

The correlation coefficients among the carcass traits of meat line FUNAAB Alpha Chicken are shown in Table 2: The results revealed that the observed values varied between $r=0.406$ (Liver Weight) and $r=0.981$ (Eviscerated weight) for the female chicken; $r=0.330$ (Head weight) and $r=$ 0.978 (Bled weight) for the male chicken. There are very high positive significant correlations between the bled weight, de-feathered weight, eviscerated weight, breast weight, thigh weight, back weight, shank weight, wing weight, neck weight and drumstick weight. However, whole gizzard weight, empty gizzard weight and liver weight relationship with other variables had no significant correlation. 
Table 2

Correlation coefficient among carcass traits of meat line FUNAAB Alpha Chicken Genotype.

\begin{tabular}{|c|c|c|c|c|c|c|c|c|c|c|c|c|c|c|}
\hline Traits & BdWt & DfdWt & EdWt & BtWt & TWt & BaWt & ShkWt & WingWt & NkWt & HeadWt & DkWt & WGdWt & EGdWt & LrWt \\
\hline \multirow[t]{2}{*}{ Bdwt } & & 0.956 & 0.978 & 0.870 & 0.852 & 0.818 & 0.768 & 0.938 & 0.569 & 0.757 & 0.909 & 0.516 & 0.608 & 0.484 \\
\hline & & 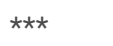 & $\star \star \star *$ & $\star \star \star *$ & $\star \star \star *$ & $\star \star \star *$ & $\star * \star$ & $\star \star \star *$ & $\star * *$ & $\star * *$ & $\star * \star$ & $\star * \star$ & $\star \star \star ~$ & $\star \star \star$ \\
\hline \multirow[t]{2}{*}{ DfdWt } & 0.958 & & 0.958 & 0.871 & 0.842 & 0.814 & 0.720 & 0.917 & 0.492 & 0.693 & 0.869 & 0.640 & 0.606 & 0.546 \\
\hline & $* * *$ & & $\star \star \star *$ & $\star \star * *$ & $\star * *$ & $\star \star \star *$ & $\star * *$ & $\star \star \star *$ & $\star * *$ & $* * *$ & $\star \star *$ & $\star * \star$ & $\star \star * *$ & $\star \star \star$ \\
\hline \multirow[t]{2}{*}{ EdWt } & 0.961 & 0.981 & & 0.900 & 0.885 & 0.813 & 0.761 & 0.953 & 0.518 & 0.730 & 0.914 & 0.484 & 0.561 & 0.465 \\
\hline & $\star \star \star *$ & $\star * *$ & & $\star \star *$ & $\star * *$ & $\star \star *$ & $\star \star \star *$ & * & $\star \star *$ & 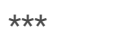 & 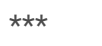 & $\star * *$ & $\star \star \star *$ & $\star \star *$ \\
\hline \multirow[t]{2}{*}{ BtWt } & 0.828 & 0.874 & 0.900 & & 0.854 & 0.690 & 0.571 & 0.858 & 0.289 & 0.557 & 0.804 & 0.430 & 0.488 & 0.447 \\
\hline & $\star * \star$ & $\star \star \star *$ & $\star \star \star \star$ & & $\star \star \star *$ & $\star \star \star *$ & $\star \star \star$ & $\star \star \star ~$ & & 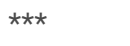 & $\star \star \star *$ & $\star \star$ & $\star \star \star ~$ & $\star \star$ \\
\hline \multirow[t]{2}{*}{ TWt } & 0.694 & 0.713 & 0.766 & 0.759 & & 0.729 & 0.593 & 0.837 & 0.424 & 0.495 & 0.853 & 0.361 & 0.395 & 0.419 \\
\hline & $\star * *$ & $\star * *$ & $\star \star \star *$ & $\star \star *$ & & $\star * *$ & $* * *$ & $\star \star *$ & ** & $* * *$ & $\star \star \star *$ & $\star$ & $\star \star$ & $\star *$ \\
\hline \multirow[t]{2}{*}{ BaWt } & 0.930 & 0.924 & 0.918 & 0.783 & 0.652 & & 0.546 & 0.776 & 0.488 & 0.575 & 0.726 & 0.398 & 0.503 & 0.407 \\
\hline & $\star * *$ & $\star \star \star *$ & $\star * *$ & $\star \star *$ & $\star * \star$ & & $\star * \star$ & $\star \star \star$ & $\star * *$ & $* * *$ & $\star * *$ & $\star *$ & $\star * *$ & $\star *$ \\
\hline \multirow[t]{2}{*}{ ShkWt } & 0.778 & 0.779 & 0.787 & 0.621 & 0.579 & 0.700 & & 0.729 & 0.564 & 0.707 & 0.698 & 0.514 & 0.519 & 0.382 \\
\hline & $\star * *$ & $\star * \star$ & $\star * *$ & $\star * \star$ & $\star \star$ & $\star \star \star$ & & $\star \star \star$ & $\star \star *$ & $* * *$ & $\star \star \star ~$ & $\star \star \star$ & $\star * *$ & $\star *$ \\
\hline \multirow[t]{2}{*}{ WingWt } & 0.697 & 0.807 & 0.802 & 0.684 & 0.606 & 0.624 & 0.722 & & 0.461 & 0.714 & 0.843 & 0.374 & 0.464 & 0.454 \\
\hline & $\star \star \star *$ & $\star \star *$ & $\star * *$ & $\star \star \star$ & ** & $\star \star \star$ & $\star \star \star *$ & & ** & 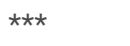 & $\star \star \star ~$ & ** & ** & 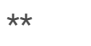 \\
\hline \multirow[t]{2}{*}{ NkWt } & 0.761 & 0.714 & 0.714 & 0.534 & 0.571 & 0.744 & 0.563 & 0.495 & & 0.506 & 0.546 & 0.176 & 0.241 & 0.265 \\
\hline & $\star * *$ & $\star * *$ & $\star \star \star *$ & $\star *$ & $\star \star$ & $\star * *$ & ** & $\star \star$ & & $* * *$ & $\star * *$ & & & \\
\hline \multirow[t]{2}{*}{ HeadWt } & 0.550 & 0.590 & 0.536 & 0.361 & 0.057 & 0.489 & 0.502 & 0.553 & 0.292 & & 0.626 & 0.389 & 0.484 & 0.330 \\
\hline & $\star \star$ & $\star *$ & $\star \star$ & & & * & $\star \star$ & $\star \star$ & & & $\star \star \star *$ & $\star \star$ & $\star \star *$ & * \\
\hline \multirow[t]{2}{*}{ DkWt } & 0.951 & 0.958 & 0.971 & 0.847 & 0.711 & 0.887 & 0.777 & 0.805 & 0.711 & 0.633 & & 0.504 & 0.535 & 0.479 \\
\hline & $\star \star \star *$ & $\star \star * *$ & $\star \star \star *$ & $\star \star \star *$ & $\star \star \star *$ & $\star \star *$ & $\star \star \star *$ & $\star \star \star *$ & $\star \star *$ & $\star * *$ & & $\star * *$ & $\star \star *$ & 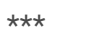 \\
\hline \multirow[t]{2}{*}{ WGdWt } & 0.410 & 0.382 & 0.328 & 0.17 & 0.151 & 0.274 & 0.339 & 0.36 & 0.387 & 0.357 & 0.381 & & 0.864 & 0.215 \\
\hline & * & & & & & & & & & & & & $\star \star \star *$ & \\
\hline \multirow[t]{2}{*}{ EGdWt } & 0.332 & 0.298 & 0.24 & 0.062 & 0.031 & 0.221 & 0.231 & 0.271 & 0.337 & 0.301 & 0.277 & 0.799 & & 0.189 \\
\hline & & & & & & & & & & & & $\star * \star$ & & \\
\hline \multirow[t]{2}{*}{ LrWt } & 0.439 & 0.457 & 0.417 & 0.356 & 0.418 & 0.406 & 0.459 & 0.473 & 0.292 & 0.276 & 0.395 & 0.173 & 0.045 & \\
\hline & * & * & * & & * & * & * & * & & & & & & \\
\hline
\end{tabular}

The scree plot is shown in Fig. 1. The scree plot is a criterion for selecting the actual number of components which would be retained for further analysis. The components having eigenvalue up to the bent of elbow in scree plot are generally considered (Dalal et al., 2020). Only the first two components have eigenvalues greater than 1 . This accounts for $78 \%$ of the total variance. However, there is a small drop between components 2,3 and 4. Components 5 through 14 appeared at the bottom of the plot. Component 1 to 7 accounts for $95.66 \%$ of the total variance.

The eigenvalues and shares of variance along with the rotated factor loading and communalities for the carcass traits of the meat line of FUNAAB Alpha Chicken Genotype at 8 weeks old are presented in Table 3. The communalities represents the estimates of variance for each variable accounted by the components. This ranged from $0.113-0.983$ in the traits. The eigenvalues showed the number of variances out of the total variance explained by each factors. Seven principal components PC1 to PC7 was extracted. PC1 to PC7 contributed $95.66 \%$ while PC1 accounted for $68.68 \%$ of the total variance. Furthermore, the varimax rotation method of principal component analysis indicated that the carcass traits that contributed significantly to PC1 were bled weight, eviscerated weight, drumstick weight and wing weight, while PC2 displayed that whole gizzard 
weight and empty gizzard contributed to the total variance. The communalities obtained for some traits were at high range. The highest was from liver weight while the lowest was from bled weight.

Table 3

Eigenvalues and shares of total variance along with rotated factor loading and communalities for carcass traits of meat line of FUNAAB Alpha Chicken Genotype at 8 weeks of age.

\begin{tabular}{|c|c|c|c|c|c|c|c|c|}
\hline Traits & PC1 & PC2 & PC3 & PC4 & PC5 & PC6 & PC7 & Communalities \\
\hline Bled weight & 0.317 & -0.032 & -0.001 & -0.064 & -0.028 & 0.082 & -0.009 & 0.113 \\
\hline Defeathered weight & 0.314 & -0.052 & -0.088 & 0.009 & -0.024 & 0.128 & -0.02 & 0.126 \\
\hline Eviscerated weight & 0.316 & -0.106 & -0.099 & -0.076 & -0.091 & 0.007 & 0.004 & 0.135 \\
\hline Breast weight & 0.275 & -0.197 & -0.423 & 0.02 & -0.124 & 0.056 & 0.293 & 0.398 \\
\hline Thigh weight & 0.26 & -0.299 & -0.32 & -0.061 & 0.291 & -0.341 & 0.044 & 0.466 \\
\hline Back weight & 0.282 & -0.104 & -0.031 & -0.147 & 0.071 & 0.568 & -0.642 & 0.853 \\
\hline Shank weight & 0.274 & 0.065 & 0.278 & 0.011 & -0.099 & -0.646 & -0.531 & 0.866 \\
\hline Wing weight & 0.295 & -0.08 & -0.032 & 0.088 & -0.263 & -0.134 & 0.073 & 0.195 \\
\hline Neck weight & 0.218 & -0.077 & 0.562 & -0.48 & 0.481 & 0.055 & 0.307 & 0.928 \\
\hline Head weight & 0.245 & 0.157 & 0.417 & 0.046 & -0.619 & 0.133 & 0.24 & 0.719 \\
\hline Drumstick weight & 0.306 & -0.055 & 0.038 & -0.051 & -0.004 & -0.041 & 0.227 & 0.154 \\
\hline Whole Gizzard weight & 0.199 & 0.616 & 0.145 & 0.078 & 0.247 & -0.163 & 0.08 & 0.540 \\
\hline Empty Gizzard weight & 0.194 & 0.638 & 0.187 & -0.039 & 0.107 & 0.171 & -0.002 & 0.522 \\
\hline Liver weight & 0.195 & -0.123 & 0.272 & 0.845 & 0.344 & 0.146 & 0.051 & 0.983 \\
\hline Eigenvalue & 9.614 & 1.305 & 0.712 & 0.681 & 0.546 & 0.332 & 0.199 & \\
\hline$\%$ Of Variation & 68.6 & 9.3 & 5 & 4.8 & 3.9 & 2.3 & 1.4 & 95.3 \\
\hline Cumulative $\%$ of Variation & 68.6 & 77.9 & 82.9 & 87.7 & 91.6 & 93.9 & 95.3 & \\
\hline
\end{tabular}

The original inter-dependent carcass traits and the independent principal components (orthogonal) was used to determine bled weight of the chicken. This is seen in Table IV. Eviscerated weight accounts for $95 \%$ of variation observed in bled weight while inclusion of empty gizzard weight showed the same proportion of the explained variance, but with a lower Mallow's cp (17.11) compared to (26.73) in the first model. The model's accuracy was further improved $R^{2}=96 \%$ when neck weight was added to the equation. The best prediction equation $\left(R^{2}=96.3 \%\right)$ was however obtained with a combination of eviscerated weight, neck weight, empty gizzard weight and liver weight. The highest single contributor $\left(R^{2}=95 \%\right)$ to the variation in bled weight of meat line FUNAAB Alpha chickens was eviscerated weight. In this present study, PC1 as a single predictor explains $96.4 \%$ of the total variability in bled weight of meat line FUNAAB Alpha chickens. However, a combination of PC1 and PC4 shows an improvement in the total variance explained $\left(R^{2}=96.7 \%\right)$ with a lower Mallow's cp (5.31)

Table 4

Stepwise multiple regression of carcass traits of meat line of FUNAAB Alpha Chicken Genotype at 8 weeks of age.

\begin{tabular}{|c|c|c|c|c|}
\hline Model & Predictors & Models & $C(p)$ & R2 \% \\
\hline \multicolumn{5}{|c|}{ Original carcass traits as predictors } \\
\hline 1 & EdWt & $B d W t=149.33+1.10 E d W t$ & 26.73 & 95 \\
\hline 2 & EdWt, EGdWt & $B d W t=113.65+1.05 E d W t+2.45 E G d W t$ & 17.11 & 95 \\
\hline 3 & EdWt, NkWt, EGdWt & $\mathrm{BdWt}=78.80+0.97 \mathrm{EdWt}+1.56 \mathrm{NkWt}+2.47 \mathrm{EGdWt}$ & 8.61 & 96 \\
\hline 4 & EdWt, NkWt, EGdWt, LrWt & $B d W t=52.90+0.93 E d W t+1.53 \mathrm{NkWt}+2.53 E G d W t+2.64 L r W t$ & 5.48 & 96.3 \\
\hline \multicolumn{5}{|c|}{ Principal components as predictors } \\
\hline 1 & PC1 & $\mathrm{BdWt}=1122.85+48.85 \mathrm{PC} 1$ & 9.05 & 96.4 \\
\hline 2 & PC1, PC4 & $\mathrm{BdWt}=1122.85+48.85 \mathrm{PC} 1-9.89 \mathrm{PC} 4$ & 5.31 & 96.7 \\
\hline
\end{tabular}


Diverse factors which includes genetics, age, live weight and sex affects meat yield, composition and quality (Khan et al., 2018). The present results showed sex associated differences in the carcass traits measured, with higher values found in the male FUNAAB Alpha chicken genotype. The apparent sex-related differences could be attributed to the average sex differential hormonal effects on the growth (Yakubu et al., 2009a), and sexual dimorphism (Baeza et al., 2001) of chicken. According to Van der Heide et al. (2016), genes for important economic traits may be differently expressed in males and females. The average bled weights observed in this study are lower compared to that of Akanno et al. (2007); Udeh and Ogbu (2011), who reported 1.88kg (Arbor Acre), $1.81 \mathrm{~kg}$ (Ross) and $1.65 \mathrm{~kg}$ (Marshal), this however could be due to the differences in the strain of birds used.

The positive relationship amongst bled weight and the carcass traits reveals that the weight can be predicted from the carcass traits in these chickens. Similar observations were made by Ajayi et al. (2008); Akporhuarho and Omoikhoje (2017). This asserts that the morphological traits are interrelated and indicate high predictability among the variables. Similar findings were reported by Udeh and Ogbu (2011), who opined that the correlation values revealed the pattern amongst the variables. Positive correlations of these traits suggest also that the traits are under the same gene action (pleiotropy) while selection for a trait might lead to a correlated response for the other traits (Yakubu et al., 2009a; Adenaike et al., 2015).

The PC approach reduced the fourteen variables into seven components for better description of carcass traits of FUNAAB Alpha chicken. PC1 had high loadings on bled weight, de-feathered weight, eviscerated weight and drumstick weight, this is largely associated with body size and accounts for $68 \%$ of the variations amongst the traits. Whole gizzard weight and empty gizzard weight were the major contributors to PC2, which can be associated with internal traits. Other PCs had low contributions to the total variation in the carcass traits. However, these PCs could be vital in evaluation of animals for breeding and selection purposes and these can be a criteria for improvement in the body weights of indigenous chickens (Ajayi et al., 2012; Egena et al., 2014; Vilakazi et al., 2020). In this study, using PC1 as a single predictor explains $96.4 \%$ of the total variability in the carcass traits. This is lesser than the findings of Ajayi et al. (2012); Egena et al. (2014), who reported PC1 explaining $68.2 \%$ of the variability in the body weights of indigenous Nigerian chickens. Combining PC1 and PC4 led to $0.3 \%\left(R^{2}=96.7 \%\right)$ improvement in the variance explained in the chicken trait with a lesser Mallow's cp. The accuracy of the model improved greatly as the principal components were included as predictors of bled weight, whilst the variability in the interdependent variables used in weight estimation between sexes support the dimorphism expressed in the descriptive analysis. Principal component regression was seen to be applicable in this study in predicting the bled weight using orthogonal variable traits.

\section{Declarations}

\section{ACKNOWLEDGEMENT}

Special thanks to the staff and management of the PEARL (Program for Emerging Agricultural Research Leaders), Poultry Breeding unit of the Directorate of University Farms (DUFARMS), for their support and assistance during the course of this project.

CONFLICT OF INTEREST: Author has declared no conflict of interest.

DECLARATION: This paper has not been published in any journal outlet and all the authors gave their consent for the pubication of the manuscript

FUNDING: This research did not recieve any from of funding from any sector

Ethics Approval: The protocol for the experiment was approved by Animal Care and Use Committee of College of Animal Science and Livestock Production, Federal University of Agriculture, Abeokuta, Ogun State Nigeria.

Consent to participate: Not applicable

Consent for publication: Not applicable

Availability of data and materials: The data are available upon request

Code availability: The code for analysis are available upon request

Authors Contribution: Wheto, M. was involved in conceptualisation, investigation, data collection and manuscript writing; Chima, N.G. was involved in the investigation, data collection and manuscript writing; Ojoawo, H.T. was involved in the data collection; Adeleke, M.A. was involved in investigation and data analysis; Peters, S.O. was involved in manuscript write up and corrections; Yakubu, A. was involved in data analysis and manuscript write up, Adebambo, A.O. was involved in investigation and correction of the manuscript, Adebambo, O.A. was involved in correction of manuscript and overall supervision.

\section{References}

Acha, C. K. 2012. Regression and Principal Component Analyses: A Comparison Using Few Regressors. American Journal of Mathematics and Statistics 2(1): 1-5 
Adebambo, O., Adebambo, A., Adeleke, M., Adeleye, A., Adetunji, A., Ajayi, F., Akinola, W., Alabi, O., Bamidele, O., Dessie, T., Ikeobi, C., Ogundu, U., Ojoawo, H., Osinbowale, D., Ozoje, M., Peters, S., Sonaiya, B., Wheto M. and Yakubu, A. 2018. Genetic Conservation through Effective Utilization of the Improved Indigenous Chicken Breeds by Rural Households in Nigeria. Proceedings of the World Congress on Genetics Applied to Livestock Production, Auckland, New Zealand. Paper No: 1117

Adenaike, A. S., Akpan, U and Ikeobi, C. O. N. 2015. Principal Components Regression of Body Measurements in Five Strains of Locally Adapted Chickens in Nigeria. Thai Journal of Agricultural Science 48(4): 217-225

Ajayi, F. O., Ejiofor, O and Ironkwe, M. O. 2008. Estimation of Body Weight from Body Measurements in Two Commercial Meat- Type Chicken. Global Journal of Agricultural Science 7(1): 57-59

Ajayi, O.O., Adeleke, M.A., Sanni, M.T., Yakubu, A., Peters, S.O., Imumorin, I.G., Ozoje, M.O., Ikeobi, C.O.N and Adebambo, O.A., 2012. Application of Principal Component and Discriminant Analyses to Morpho-structural Indices of Indigenous and Exotic Chickens Raised Under Intensive Management System. Trop. Anim. Health. Prod. 44, 1247-1254.

Akanno, E. C., Ole, P. K., Okoli, I. C and Ogundu, U. E. 2007. Performance Characteristics and Prediction of Body Weight of Broiler Strains using Linear Body Measurements. Proceedings 22nd Annual Conference of the Nigerian Society for Animal Production, Calabar: $162-164$.

Akporhuarho, P.O and Omoikhoje, S. O. 2017. Principal Component Analysis Of Body Weight And Biometric Traits Of F1 Crossbred Of Exotic Broilers $\mathrm{X}$ Local Chickens. Nigerian Journal of Science and Environment, Vol. 15:1

Alabi, O.O., Ajayi, F.O., Bamidele, O., Yakubu, A., Ogundu, E.U., Sonaiya, E.B., Ojo, M.A., Hassan, W.A and Adebambo, O.A. 2020. Impact Assessment of Improved Chicken Genetics on Livelihoods and Food Security of Smallholder Poultry Farmers in Nigeria. Livestock Research for Rural Development 32(5)

Amao, S. R. 2018. Application of Principal Component Analysis on the Body Morphometric of Nigerian Indigenous Chickens reared intensively under Southern Guinea Savanna Condition of Nigeria. Journal of Environmental Issues and Agriculture in Developing Countries. Volume 10, Number 1

Baeza, E., N., Williams, D. G and Duclos, M. J. 2001. Sexual Dimorphism For Growth in Muskovy Duck and Changes In Insulin-like Growth Factor I (IGF- I), Growth Hormone (GH) and Triiodothyronine (T3) plasma levels. Reprod. Dev. 41: 173-179.

Dalal, D.S., Poonam, R., Malik, B.S., Patil, C.S and Manoj, K. 2020. Analysis of Morphological Traits of Synthetic White Leghorn Chicken. Indian Journal of Animal Sciences 90 (11): 1551-1555

Egena, S., Ijaiya, A.,Ogah, D and Aya, V., 2014. Principal Component Analysis of Body Measurements In A Population of Indigenous Nigerian chickens Raised Under Extensive Management System. Slovak J. Anim. Sci. 47, 77-82.

Khan, U., Hussain, J., Mahmud, A., Khalique, A., Mehmood, S., Badar, I. H., Usman, M., Jaspal, M. H., Ahmad, S. 2018.Comparative Study on Carcass Traits, Meat Quality and Taste in Broiler, Broiler Breeder and Aseel Chickens. Brazilian Journal of Poultry Science, eRBCA-2019-0770

Kleczek, K., Wawro, K., Wilkiewicz-Wawro, E and W. Makowski. 2006. Multiple Regression Equations to Estimate the Content of Breast Muscles, Meat, and Fat in Muscovy Ducks. Poultry Science, 85:1318-1326

Lieberman, Mary G and Morris, John D. 2008. Mallow's Cp for Selecting Best Performing Logistic Regression Subsets. Multiple Linear Regression Viewpoints, Vol. 34(1)

Pinto, L., Fernando, B., Irineu, U., Cláudio, M. R., Mônica, C., Luiz, L. 2006. Principal Components Analysis Applied To Performance And Carcass Traits In The Chicken. Anim. Res. 55: 419-425

Saleh, B., Mbap, S.T., Kalla, D.J.U., Doma, U.D. and Duwa, H. 2017. Effect of Varying Levels of Dietary Energy and Protein on Reproductive Performance of FUNAAB - Alpha Hens. Livestock Research for Rural Development 29 (3) 2017

Udeh, I and Ogbu, C. C. 2011. Principal Component Analysis of Body Measurement in Three Strains of Broiler Chicken. Science World Journal, 6 (2): $11-14$

Van der Heide, E. M., Lourenco, D. A., Chen, C. Y., Herring, W. O., Sapp, R. L., Moser, D. W., Tsuruta, S., Masuda, Y., Ducro, B. J., Misztal, I. 2016. Sexual Dimorphism in Livestock Species Selected For Economically Important Traits. Journal of Animal Science 94: 3684-3692. doi: 10.2527/jas.20160393.

Vilakazi, B. N., Ncobela, C. N., Kunene, N. W and Panella, F. 2020. Determining the Morphological Structure Of Indigenous Chickens Using Multivariate Principal Component Analysis of Body Measurements. Appl. Anim. Husb. Rural Develop. 2020, (13): 69-75 
Yakubu, A, Kingsley, O. I and Agade, Y. 2009b. Using Factor Scores In Multiple Linear Regression Model For Predicting The Carcass Weight Of Broiler Chickens Using Body Measurements. Revista UDO Agrícola 9 (4): 963-967.

Yakubu. A., Kuje, D and Okpeku, M. 2009a. Principal Component as Measures of Size and Shape in Nigerian Indigenous Chickens. Thai Journal of Agricultural Science, 42(3): 167-176.

\section{Figures}

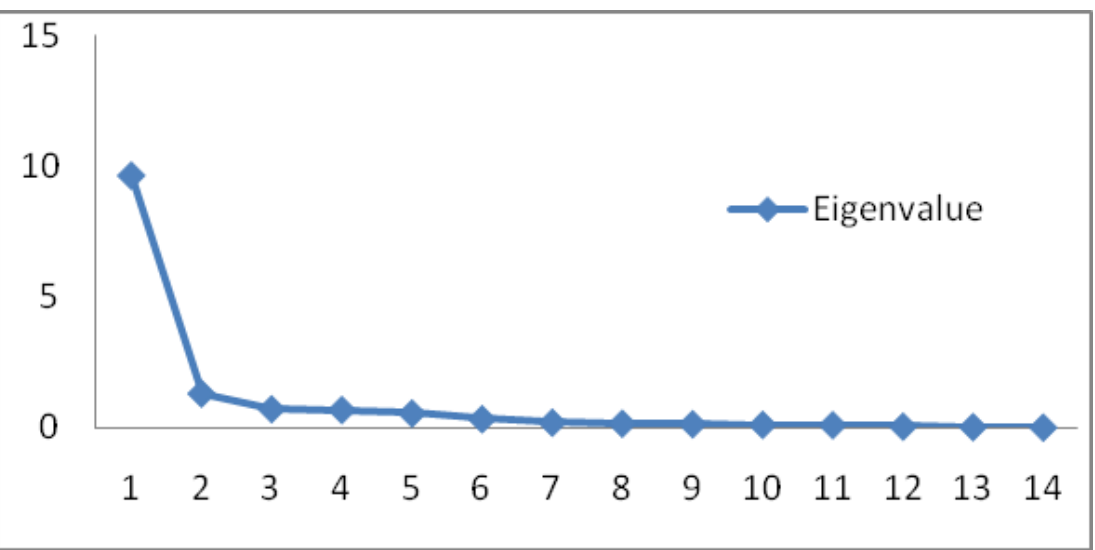

\section{Figure 1}

Scree plot of eigenvalues 